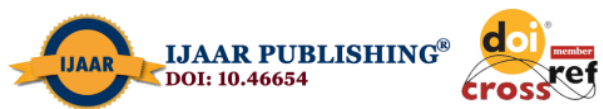 \\ Scholarly Journal of Advanced Legal Research | ISSN: 2782-8220 \\ Vol. 1, Issue 5 (May, 2021) |www.ijaar.org \\ Journal DOI: www.doi.org/10.46654/SJALR \\ Article DOI: www.doi.org/10.46654/SJALR.1541
}

\section{THE LEGAL PRACTITIONERS PROFESSIONAL NEGLIGENCE IN NIGERIA: EVALUATION OF THE GENERAL LIABILITY AND IMMUNITY AFFORDED ON LEGAL PRACTITIONERS IN THE CONDUCT OF THEIR CLIENT'S CASE}

\author{
OLUWAKEMI ODEYINDE, LLM (UNILAG) BL (UI) \\ LAW LECTURER II \\ CENTRE FOR FOUNDATION EDUCATION \\ BELLS UNIVERSITY OF TECHNOLOGY OTA, NIGERIA \\ E-MAIL: kemiodeyinde@gmail.com \\ CONTACT NUMBERS: 08178312706; 08056682060
}

\begin{abstract}
This paper reviews the legal practitioner's professional negligence in Nigeria and the rule of law exempting lawyers from liability for negligence in the conduct of proceedings in court, tribunal or other body. The introduction reminds us of the historical development of the legal profession. It examines the concept of professional negligence which involves misconduct or malpractice in the course of practicing one's profession. The law places more responsibility on the professional in the exercise of judgment. Therefore the standard of care expected of a professional is high. The general rule is that a legal practitioner can be held liable for professional negligence. He may also be found guilty of professional misconduct or malpractice where he contravenes any of the rules of professional conduct. However, there exists a law in Nigeria that grants immunity to legal practitioners from negligent acts in the conduct of their client's case. This paper explores the origin of the lawyer's immunity. It argues that the exemption granted lawyers in respect of court proceedings does not help the fallen standards of the legal profession in Nigeria. As a result, there is a general consensus among writers as to the removal of the immunity clause. Therefore, this paper examines the various advocates for the removal of the lawyer's immunity and suggests a reconsideration for its possible removal. This paper concludes with a recommendation for a more pragmatic approach to maintaining the standards of the Legal Profession. The term professional negligence is used interchangeably with professional misconduct or malpractice.
\end{abstract}

Key Words: Legal practitioner, legal profession, negligence, professional negligence, immunity, liability 


\subsection{INTRODUCTION}

The law of Professional Negligence is a concept developed from the tort of negligence. The basic element that is needed to succeed in a claim of negligence is the existence of a duty of care. The courts are gradually extending the scope of the tort of negligence. Thus professional negligence deals with instances where a person has represented him or herself to possess more than the average skills and knowledge in certain areas. This is because professionals in all areas of works are expected to exercise a reasonable standard of care in their work. Failure to take such care and which causes injury to the person relying on it will amount to professional negligence. This paper particularly deals with the legal issues surrounding the legal practitioner's professional negligence in Nigeria. Of great concern is the issue with regards to the various misconduct and malpractice in the legal profession. In relation to this, is the limitation placed on the range of situations where a legal practitioner can be held liable for negligence in Nigeria? The current position of the law grants immunity to a lawyer during litigation. The immunity accorded lawyers has been given much attention over the years, thereby creating a lot of arguments for its removal. This study critically analyses the issues surrounding the immunity.

The objective of this study is to explore the concept of professional negligence in the legal profession. This will be done by examining the standard of care in relation to the legal profession. Also, the liability of lawyers to their client will lead to a thorough examination of the Rules of Professional Conduct. The Legal Practitioners Act also makes mention of infamous conduct in professional respect which includes any conduct that constitutes a breach of the acceptable standard of behaviour in the legal profession. It also includes any conduct which is dishonourable as to ridicule the legal profession. ${ }^{1}$ An exploration of the circumstances surrounding professional misconduct in the legal profession will also be examined. This paper will also examine the state of the legal profession in terms of the numerous misconduct and malpractice in the profession.

Afterwards, the rise of the lawyer's immunity will be explored, with the analysis of the famous English cases that led to the development of the immunity. Observations of the various jurisdictions that have abolished the whole concept of lawyer's immunity will be looked into. Then a discussion of the rule of law exempting lawyers in Nigeria from liability from negligence will be critically examined. In the final analysis, this paper makes a clarion call for a thorough purging of the bar from miscreant's and reckless behaviours in the legal profession in Nigeria.

\subsection{History of the Legal Profession in Nigeria}

The Legal Profession is a very noble profession, built on ethics, etiquette and decorum. ${ }^{2}$ It is a profession that everyone one holds with high esteem. According to the Legal Practitioners Act, ${ }^{3}$ a legal practitioner means "a person entitled in accordance with the provisions of this Act to practice as a barrister or as a barrister and solicitor, either generally or for the purposes of any particular office or proceedings." In Nigeria a legal practitioner practices both as a barrister and a solicitor. This is quite different in other countries such as England where barristers and solicitors are practised separately. In order to preserve the integrity of the legal

\footnotetext{
${ }^{1}$ S 11 LPA Cap 207 LFN ; M.D.P.D.T. v. Okonkwo (2001) 6 NWLR 710 ; (2001) 3 SC 76; (2001) All NLR 305

${ }^{2}$ Yenkarti \& Anor v Abbah \& Ors (2017) LPELR-43032(CA)

${ }^{3}$ S24 LPA
} 
profession, there are rules and conduct which guide it. Unfortunately, the high standard and values expected of the Legal profession are gradually fallen. Of great concern are the cases of misconduct which characterise the legal profession in Nigeria.

The history of the Nigerian legal profession can be traced back to England which colonised us. In 1863 when the English people landed in Lagos, it became a British colony and so all the English laws were introduced into Lagos. The Supreme Court ordinance 1876is the first significant statutes on legal practice. The act provides that 'The Chief Justice shall have power to approve, admit and enroll to practice as barristers and solicitors in the court such persons as shall have been admitted as solicitors.... in any courts of London, Dublin and Edinburgh. 'The Chief Judge had the power to admit anyone to practice as a barrister and a solicitor so long as the person was also entitled to practice as a barrister in England and Ireland or as an advocate in Scotland and persons who could produce testimonials to show evidence of good character. Therefore in order to qualify to practice as a legal practitioner in Nigeria, one must be called to the English, Scottish or Irish bar. As a result of our customary system, this created a lot of problems for the people of Nigeria. The legal profession was created to suit the needs of the colonial masters rather than the Nigerians. Therefore when Nigeria gained independence in 1960, it became necessary to develop a legal education for the Nigerian people. This led to the enactment of the Legal Education Act of 1962. The Act created the Council of Legal Education (the Council). Its Functions is to provide legal education for Africans who seek to be members of the legal profession. The Council then established the Nigerian Law school which educates aspiring young lawyers in the practice of law by offering professional courses, the practice of the law through court attachments, law office management, Advocacy, legal drafting, Solicitors Account Management etc. The Nigeria Law School is a great training ground to raise aspiring young lawyers to be noble in their Profession. Up to date, the Council continues to maintain high standards in the Legal profession in Nigeria.

\subsection{The Concept of Professional Negligence}

A " Profession includes the performance of any type of personal service to the public which requires as a condition precedent to the performance of such service the obtaining of a license or admission to practice or other legal authorization" "It includes personal services rendered as an architect, dentist, optician, physician, engineer, veterinarian, certified public accountant or surgeon, an attorney at law etc. ${ }^{5}$ Being a Professional mean the possession of the requisite skills and expertise in the field. Most professionals are subject to certain rules of professional conduct which is binding upon them. There are certain duties expected of someone who is regarded as a professional. Such duties are expected to be carried out with the utmost care and diligence. Where a professional fails to exercise due care and diligence in his profession, he can be held liable for negligence. It is now an established law that where a person acts in a professional capacity without due care or diligence, he will be liable for any injury arising from such act or omission." Professional negligence, therefore, is a breach of duty of care owed by professionals to their clients. It usually involves misconduct or malpractice committed in the course of one's professional's practice. It envisages a situation where one may be liable for a tort committed when practising one's profession. The conduct that

\footnotetext{
${ }^{4}$ 'Professional Negligence'(1973) (121)(3)University of Pennsylvania Law Review;627 ${ }^{5}$ Ibid

${ }^{6}$ Mr Ray Akanwa v Hon. Sylvester Ogbaga (2016) LPELR-41054(CA); Afribank Plc v Akwara (2006) 5 NWLR pt. 974, 619
} 
amounts to professional negligence or misconduct is also determined by the body or associations to which the professional belongs. ${ }^{7}$

Professional Negligence is a fragment of the English tort of negligence and touches on areas where a person has represented himself or herself to possess skills and expertise in certain aspects. It has been defined as "that special form of competence which is not part of the ordinary equipment of the reasonable man, but which is the result of acquired learning, and aptitude developed by special training and experience, and which distinguish the professional and the skilled tradesman from the ordinary reasonable man" ${ }^{\prime 8}$ One factor which distinguishes a professional from other persons is the exercise of his intellectual judgement and skills. He is one in whom by virtue of his education and training, his judgment and expertise are relied upon. He is seen as an authority by people who look up to him. The law, therefore, places a lot of responsibility on the professional in the exercise of judgment, hence the development of the term "professional liability" The law of professional negligence has developed in the following areas: Accountants and auditors, bankers, Architects, Engineers, Medical practitioners, legal practitioners etc. As the profession increases and professionalism becomes the enviable standard, the burden upon the professional increases, the law of tort must respond to the development.

\subsection{The Standard of Care required of a Professional}

The rule that has guided the court in their decisions is that the professional must exercise reasonable care and the measure of skill and knowledge ordinarily possessed by members in good standing of his profession. ${ }^{9}$ In some professions, the standard of care is determined by the standard that would be exercised by a reasonable person in that line of profession. This is known as the Bolam test which originated from the English case, Bolam v Friern Hospital Management Committee. ${ }^{10}$ The Bolam case established the rule for determining the standard of care in negligence cases involving professionals which in this case was a doctor. In the case a patient sued his doctor for not warning him about the risk involved with respect to a particular treatment. The expert witness who gave evidence claimed that it was the usual practice not to warn patients of the risk of this particular treatment beforehand unless they are asked. The court held that what was the usual practice in a particular profession is highly relevant to the standard of care. When a person has represented himself or herself as a professional "as all doctors do", the standard of care will be higher. However the standards must be in accordance with a responsible body of opinion, even if others differ in opinion. For this reason, the Bolam test states that "If a doctor reaches the standard of a responsible body of medical opinion, he is not negligent". ${ }^{11}$ The Bolam test was revised and in the case of Hedley Byrne \& Co Ltd v Heller \& Partners Ltd, the court stated thus:

\footnotetext{
${ }^{7}$ Doughty v General Dental Council (1987) 3 ALL ER 179

${ }^{8}$ Supra note 4, 630

${ }^{9}$ Ibid

${ }^{10}(1957) 1$ WLR 582

${ }^{11}$ Ibid 587
} 
"Where a person is so placed that others could reasonably rely upon his judgment or his skill or upon his ability to make careful inquiry, and a person takes it upon himself to give information or advice to, or allows his information or advice to be passed on to, another person who, as he knows or should know, will place reliance upon it, then a duty of care will arise." $^{12}$

In other words as a professional whose knowledge and expertise is relied on, there is a standard of care to give all the necessary information that will be of benefit to the person relying on it.

\subsection{Lawyers Liability for Professional Negligence}

The position of the law with respect to the tort of negligence is that "a legal practitioner stands in the same position under the law as any other person." ${ }^{13}$ Just like any other profession, he is expected to exercise reasonable care and skill in his legal practice. Lord Rusell and Lord Keith stated thus in the case of Saif Ali v Mitchel \& Co as follows, 'the principle that a professional person who held himself out as qualified to practice that profession was under a duty to use reasonable care and skill and was not to be given any wider application than was immunity necessary in the interests of the administration of justice. $^{14}$

Professional Negligence may arise from negligent misstatements and other professional liabilities or negligent conducts. In the case of negligent misstatement by lawyers in the Hedley Byrne v Heller case, ${ }^{15}$ the house of lords considered whether a duty of care arose in an action for negligent misstatement when they said, 'I consider that it follows and that it should now be regarded as settled that if someone possessing special skill undertakes, quite irrespective of contract, to apply that skill for the assistance of another person who relies upon such skill, a duty of care will arise.' The court held that a negligent misstatement may give rise to an action for damages when there is an economic loss. It was stated by the court that 'when a party seeking information or advice from another - possessing a special skill and trusts him to exercise due care, and that party knew or ought to have known that the first party was relying on his skill and judgment, then a duty of care will be implied'. ${ }^{16}$ Before this decision by the court, the idea that a person may owe a duty of care to another that relies on the statements or advice given had been rejected and there was no remedy available in the tort of negligence except for remedies in contract law. The House of Lords overruled the previous position and accepted that liability thus exits from pure economic loss although not arising from a contractual relationship and the court introduced a new idea termed 'assumption of responsibility'. ${ }^{17}$ A Legal Practitioner may, therefore, be liable for negligence in the following instances: where he gives wrong advice, brings an action that is statute-barred, delays in instituting proceedings that leads to the action becoming statute-barred, delays in entering an

\footnotetext{
12 (1964) AC 465

${ }^{13}$ Saif Ali v Mitchel \& Co(1980) AC 198; (1978) 3 All ER 1033

${ }^{14}$ Ibid

${ }^{15}$ See supra note 13

${ }^{16}$ Ibid

${ }^{17}$ Paul T. Hayden'Reconsidering the Litigators Absolute Priviledge to Defame' (1993)(54) Ohio State Law Journal, 985
} 
appearance or serves defence that leads to default judgment being obtained against his client, failure to prosecute a case, with due diligence that leads to the case being struck out for want of prosecution etc

In Nigeria the law which makes a legal practitioner liable for professional negligence is enshrined in Section 9 of the Legal Practitioners Act, CAP 207 LFN as follows:

9(1) Subject to the provisions of this section, a person shall not be immune from liability for damage attributable to his negligence while acting in his capacity as a legal practitioner, and any provision purporting to exclude or limit that liability in any contract shall be void.

(2) Nothing in subsection (1) of this section shall be construed as preventing the exclusion or limitation of the liability aforesaid in any case where a legal practitioner gives his services without reward either by way of fees, disbursements or otherwise.

(3) Nothing in subsection (1) of this section shall affect the application to a legal practitioner of the rule of law exempting barristers from the liability aforesaid in so far as that rule applies to the conduct of proceedings in the face of any court, tribunal or other body.

This liability for lawyers negligent is a common law position which has been embedded in our laws. By virtue of section 9(1), the general rule is that a legal practitioner can be held liable for professional negligence. However, there is an exception to this general rule which is contained in Section 9(2) and (3) of the Act. In other words, there are two instances where a lawyer is exempted from liability for professional negligence. The first instance is where he acts gratuitously to his clients and secondly where he acts as a barrister or advocate in the course of judicial proceedings. We shall first consider the general rule as regards the lawyer's liability for professional negligence and then consider the two exceptions.

The courts in Nigeria have made it clear that a lawyer can be held liable for professional negligence. In Chidoka \& Anor v First City Finance Company Limited ${ }^{18}$ one of the issues for determination by the Supreme Court was to consider circumstances where a counsel can be sued for professional negligence. In the instant case, the counsel deliberately refused to call any witness. To this, the court stated that 'A counsel is a master of the case he conducts. He may decide not to call any witness or witnesses of the other party. However, where a counsel negligently conducts his client's case, he is liable to be sued for professional negligence. 'The level of trust reposed upon a legal practitioner and the expertise possessed by such position makes him liable where such trust is broken. The courts have established the fact that the relationship between a client and his legal practitioner is contractual in nature. ${ }^{19}$ Consequently the general duty of care expected of a legal practitioner in Nigeria is to avoid a

\footnotetext{
18 (2012) LPER-9343(SC)

${ }^{19}$ Edozien v. Edozien (1993) 1 SCNJ 166,189; Mosheshe v NSP Ltd (1986) 2 NWLR (pt.55) 110, 119; Adewunmi v Plastex Nig. Ltd. (1986) 6 SC 214, 223.
} 
breach of that contract. To determine the liabilities of a lawyer to his client it is necessary to examine the duties of a lawyer in this regard.

\subsection{The Duty of a Lawyer in the conduct of his client's case}

In order to succeed in an action for negligence, there is a need to prove that a duty of care exists. In other words in the tort of negligence, lawyers owe a legal duty to exercise reasonable care. Generally, in the law of Negligence, we owe a duty of care to anyone who is likely to be affected by our acts or omissions. For professional negligence, the standard of care is a higher one and depends upon the relationship that exists between the parties. A lawyer, therefore, has a legal duty to exercise reasonable skill, diligence and expertise while dealing with his clients. A lawyer does not owe a duty to everyone he meets on the road that is in trouble and needs legal advice. Such duty is a moral one which the law does not require him to fulfil. He has a choice whether or not to fulfil this moral obligation. But when a client engages his service, he has a legal duty to exercise due care and diligence in the conduct of his case. It is the duty of a lawyer to dedicate his 'attention, energy and expertise to the service of his client ${ }^{20}$ and to act in his best interest. ${ }^{21} \mathrm{He}$ has a duty to handle his client's case with "utmost devotion". 22 Such devotion must carry with it a certain level of professionalism. ${ }^{23}$ Negligence in the handling of a client's case may, therefore, amount to professional Negligence. ${ }^{24}$

The lawyer's behaviour is subject to compliance with certain code of conducts. As a result, they owe a duty to the clients they represent to act within these laid down code. ${ }^{25}$ In Nigeria, the Lawyer's duty is prescribed by the Rules of Professional conduct. The Rules of Professional Conduct is established to maintain the highest standard of professional conduct, etiquette and discipline in the legal profession. The legal practitioner in Nigeria is therefore expected to sustain such standards in his legal practice.

The general duty of a lawyer is to 'uphold and observe the rule of law, promote and foster the course of justice, maintain a high standard of professional conduct, and shall not engage in any conduct which is unbecoming of a legal practitioner. ${ }^{26}$ Unfortunately, the conduct of many lawyers in Nigeria does not measure up to such high standards. ${ }^{27} \mathrm{~A}$ lawyer's devotion to the cause of his client must be carried out within the bounds of the law. He is to handle his client's case using his professional judgement. ${ }^{28}$ In other words, a lawyer has a duty to provide competent representation. A lawyer must be prepared at all times and there must be no conflict of interest while discharging his duty as a lawyer.

In Nigeria there are several cases of Professional misconduct which the court have not taken lightly too. What the courts have done in some cases is to overturn the convictions ${ }^{29}$ or

\footnotetext{
${ }^{20}$ Rule 14(1) of the Rules for Professional Conduct for Lawyers (RPC) 2007

${ }^{21}$ Ibid

${ }^{22}$ Adewunmi v Plastex Nigeria limited (1986) NWLR (Pt. 32),767

${ }^{23}$ Ibid

${ }^{24}$ Rule 14(5) RPC

${ }^{25}$ Dariye v FRN (2015) LPELR- 24398 (SC)

${ }^{26}$ Rule $1 \mathrm{RPC}$

${ }^{27}$ Rule 14(1) RPC

${ }^{28}$ Rule 14(3) RPC

${ }^{29}$ Udofia v State(1984) 12 SC 139; Udo v State(1998) 3NWLR (Pt 82) 316
} 
dismiss an appeal for want of prosecution. ${ }^{30}$ In practice most times clients do not have the confidence to sue their lawyers for professional negligence because of the general belief that such suit will fail. It is pertinent to note therefore that the Lawyers rules of professional conduct are established to protect the rights of the client to diligent legal representation. The rules that deals with professional malpractice or misconduct are provided for under Rule 14(1) - (5); 16(1) (a) - (d); 30 and 31(3) of the Rules of Professional conduct. Rule 14(1) (5) deals with the devotion of a legal practitioner to his client's case. It provides as follows:

14(1) It is the duty of a lawyer to devote his attention, energy and expertise to the service of his client and subject to any rule of law, to act in manner consistent with the best interest of the client.

(2) Without prejudice to the generality of paragraph (1) of this rule, a lawyer shall-

(a) consult with his client in all questions of doubt which do not fall within his discretion;

(b) keep the client informed of the progress and any important development in the cause or matter as may be reasonably necessary.

(c) warn his client against any particular risk which is likely to occur in the course of the matter.

(d) respond as promptly as reasonably possible to request for information by the client, and

(e) where he considers the client's claim or defence to be hopeless, inform him accordingly.

(3) When representing a client, a lawyer may, where permissible, exercise his independent professional judgment to waive or fail to assert a right or position of his client.

(4) It is the duty of lawyer employed in respect of a Court case to be personally present or be properly represented throughout the proceedings in Court.

(5) Negligence in handling of a client's affairs may be of such a nature as to amount to professional misconduct.

Rule 16(1) (a) - (d) deals with representing a client competently:

16. (1) A lawyer shall not-

(a) handle a legal matter which he knows or ought to know that he is not competent to handle, without associating with him a lawyer who is competent to handle it, unless the client objects;

\footnotetext{
${ }^{30}$ Chime v Ude (1996) 7 NWLR (Pt 461),379; M/V Baco Liners v Emmanuel Adeniji (1993) 2 NWLR (Pt 274), 195
} 
(b) handle a legal matter without adequate preparation;

(c) neglect a legal matter entrusted to him; or

(d) attempt to exonerate himself from or limit his ability to his client for his personal malpractice or professional misconduct

In Udofia $v$ The State, ${ }^{31}$ the legal practitioner was absent when two important witnesses gave their testimony in court. His cross-examination was very weak on the days he appeared in court. When he was called upon to give the final address all he said was "I leave the matter to the court. Udofia v The State ${ }^{32}$ depicts the slackness and the lack of seriousness of some lawyers in the legal practice. As Justice Oputa J.S.C clearly puts it, in that case, 'It mirrors and reflects the general and steady decline in the standard of professional responsibility required of counsel defending an accused person...., 33

Similarly the notorious attitude of lawyers in employing delay tactics is also an act of professional misconduct. Such tactics delay the cause of justice. These among others shows the laxity with which lawyers handle their client's cause. It is now the law that the court can lawfully take action against any counsel who deliberately engages in delay tactics, without violating the provisions of Section 36(1) of the Constitution which deals with the right to a fair hearing. ${ }^{34}$ According to Rule 30 'A lawyer is an officer of the court and, accordingly, he shall not do any act or conduct himself in any manner that may obstruct, delay or adversely; affect the administration of justice' and by virtue of Rule31 (3) 'A lawyer who fails to comply with any undertaken given by him either personally or on behalf of client to a court is prima face guilty of professional misconduct. 'Depending on the facts of each case a lawyer may be punished for professional malpractice or misconduct as contained in Rules 55(1) and (2) as follows:

55.(1) If a lawyer acts in contravention of any of the rules in these Rules or fails to perform any of the duties imposed by the rules, he shall be guilty of a professional misconduct and liable to punishment as provided in Legal Practitioners Act, 1975.

(2) It is the duty of every lawyer to report any breach of any of these rules that comes to his knowledge to the appropriate authorities for necessary disciplinary action.

\footnotetext{
${ }^{31}$ (1988) LPELR-3305(SC); (1988) NWLR (Pt.84) 533; (1988) 7 S.C (Pt III) 59

${ }^{32}$ Ibid

${ }^{33} \mathrm{Ibid}$, Oputa J.S.C. giving the lead Judgment

${ }^{34}$ Eze v FRN (2017) LPELR-42097(SC), 41-43, Paras. A-A; S 36(1) of the Nigerian constitution 1999 provides that 'In the determination of his civil rights and obligations, including any question or determination by or against any government or authority, a person shall be entitled to a fair hearing within a reasonable time by a court or other tribunal established by law and constituted in such manner as to secure its in dependence and impartiality.'
} 
Similarly, in NBA v Iteogu, ${ }^{35}$ a legal practitioner was given a power of attorney by his client to claim compensation from the Federal Government for land acquired for the development of a Naval Base in Akwa Ibom. The lawyer was found to have collected the sum of almost 48 million as compensation but never remitted the amount to the client. The lawyer was found guilty of infamous misconduct. According to the judge '....any conduct that constitutes an infraction of acceptable standard of behaviour or ethics of the legal profession, of any conduct which connotes conduct despicable and morally reprehensible as to bring the legal profession into disrepute if condoned or unpunished, will amount to misconduct. ${ }^{36} \mathrm{~A}$ lawyer can, therefore, be found guilty of infamous conduct in professional respect according to Sec 11(1) (a) of the LPA. Where it is not in a professional respect, it may not fall within the provisions of sec 11(2). ${ }^{37}$ What conducts can amount to professional conduct is not defined by the rules, however, any practice of a lawyer contrary to the rules or is in breach of the rules may amount to misconduct. ${ }^{38}$ One can see from the Iteogu case that a lawyer should not abuse the confidence reposed on him by his client. The term confidentiality and trust come with the profession. Equally, a lawyer is not expected to disclose any information given to him by his client. ${ }^{39}$ And as such he is expected to keep proper account of his client's money or property. ${ }^{40}$

\section{2 Gratuitous Service by Lawyers}

The LPA has made it clear that liability will not arise in cases of gratuitous service. This seems logical as relationship between a lawyer and his client is contractual in nature. Evidence of payment of fees which serves as consideration creates a binding obligation under the law of contract. Where a party has not furnished consideration in the law of contract there can be no breach of contract. Therefore gratuitous service cannot create a binding obligation on the part of a lawyer to make him liable for professional misconduct. It is the right of a lawyer to be paid adequate remuneration for the services rendered to his client. ${ }^{41}$ As a result, the client is defined by the LPA as, 'the person or any of the persons alleged to be liable to pay the charges of a legal practitioner. ${ }^{42}$ It has been said by writers that it may seem unfair for the issue of liability to arise in cases where a lawyer renders gratuitous services. ${ }^{43}$

\subsection{The Barrister immunity clause in Nigeria}

Under the LPA there is an immunity clause which exempts barristers from liability for Negligence suits. In Nigeria, a lawyer practices both as a solicitor and a barrister but the Act only creates the immunity for lawyers acting in their capacity as a barrister. The law states that barristers are exempted from liability for negligence in the conduct of proceedings in a

\footnotetext{
35 (2009) 17 NWLR (Pt. 1171) 614 (SC); (2009) LPELR-1559(SC)

${ }^{36}$ Supra note 1; M.D.P.T v Okonkwo; Re A Solicitor Exparte Incorporated Law Society (1894) 1 QB 254,711

${ }^{37}$ Re Idowu Legal Practitioner (1971) 1 ALL NLR 126 and In the matter of Thomas James Wallace (1886) 16 ER26; Yusuf Ali 'The Future of Legal Practice in Nigeria: Regulation and Discipline in the Legal Profession.' A paper presented at the 8th Annual Business Luncheon of S. P. A. Ajibade \& Co., held in Lagos, on 26th November, 2015

38 Supra note 23, 44-45 Paras G-C

${ }^{39}$ Rule 19 RPC

${ }^{40}$ Rule 23 RPC

${ }^{41}$ Rule 48 RPC

${ }^{42}$ S19 LPA

${ }^{43}$ Supra at note 21
} 
court, tribunal or other body. However, in Bello Raji v X Legal Practitioner, ${ }^{44}$ a client sued his lawyer for negligence and reckless conduct for filing a suit on his behalf that was statutebarred. The court held that the lawyer's conduct exhibited gross carelessness and awarded damages for the client. Similarly in Cocottopoulos $v$ P. Z \& Co. Ltd ${ }^{45}$, a lawyer brought an action on behalf of his client for wrongful dismissal despite the fact that the client's contract of employment clearly stated that the client's employer can terminate his contract of employment at any time. The court observed that the conduct of the lawyer did not show reasonable professional diligence as the case lacked merit. The court ordered the lawyer to return the full professional fees. The court did not hesitate in these two cases to award damages for negligence as the conduct of both lawyers clearly proofs a lack of due care and diligence. In order to explore this concept of lawyer's immunity, it is necessary to discuss its origin.

\subsubsection{The origin of Lawyer's immunity}

The immunity granted lawyers in the course of court proceedings can be traced back to medieval England. The introduction of the lawyer's immunity pertained to cases for defamation or slander. A lawyer could make a false and damaging statement to discredit his opponent's witness during trial and would be protected by absolute immunity. For example, he could call a witness, opposing party or even the opposing party lawyer a liar, cheat, vagabond etc without fear of being sued for the statements. ${ }^{46}$ This was a long time common law Priviledge. Thus the first opinion dismissing a case against a lawyer 'can be found as far back as 1606 in a court case brought against a lawyer for the tort of slander. ${ }^{47}$ In the said case, the lawyer made a statement stating that the opposing party was a convicted felon. The opposing party therefore brought a charge of slander against the lawyer. The court held that even if the statement was false, the lawyer was protected by absolute immunity during the trial. Similarly, an attempt to claim damages against a barrister in 1791 failed in the case of Fell $v$ Bell. The action failed because according to the judge the immunity was part of a "bundle of priviledges" that also pertains to the status of judges. Lord Kenyon expressed distaste for such proceedings commenting that this was the first action against a counsel as far as he knew and hoped this would be the last. In 1883, in the case of Munster v. Lamb ${ }^{48}$, the court stated that a case against a counsel must be discontinued immediately if the allegation against the lawyer concerns what was said "in the course of the administration of law" ${ }^{49}$ In Henderson v Broomhead, the court explained thus,

\footnotetext{
44 (1946) 18 NLR 74

451965 LLR 170.

${ }^{46}$ Supra note 18

${ }^{47}$ Brook v Montague, 79 Eng. Rep. 77; (1606) KB 7; T. Leigh Anenson 'Absolute Immunity from CivilLiability: Lessons for Litigation Lawyers' (2004) 31(4) Pepp L Rev, 915

${ }^{48}$ (1883) 11 QBD 588

${ }^{49}$ Ibid.605; Rex v Skinner, 98 Eng Rep 529 (1772)
} 
No action will lie for words spoken or written in the course of any judicial proceeding. In spite of all that can be said against it, we find the rule acted upon from the earliest times. The mischief would be immense if the person aggrieved, instead of preferring an indictment for perjury, could turn his complaint into a civil action. By universal assent it appears that in this country no such action lies. ${ }^{50}$

In 1967 the immunity granted legal practitioners as regards liability for negligence was affirmed in the celebrated case of Rondel $v$ Worsley $^{51}$, where a client convicted of a criminal offence, sued his lawyer for negligence in the conduct of his defence. The House of Lords declared that a barrister was immune from an action in negligence in the conduct and management of a case in court proceedings and also preliminary work connected with it. The house of lord gave the following reason which is based on public policy, for their decision. First, the justification for the lawyer's immunity is based upon the principle of law that a lawyer's duty to the court is of paramount importance. Therefore the immunity granted lawyers are premised on the need to enable a lawyer to perform his duty to the court. A lawyer should be able to perform his duty to the court independently and fearlessly. This can be seen in the famous quote by Lord Reid in the Rondel's case:

'As an officer of the court concerned in the administration of justice [a legal practitioner] has an overriding duty to the court, to the standards of his profession, and to the public, which may and often does lead to a conflict with his client's wishes or with what the client thinks are his personal interests. ${ }^{52}$

The House of Lords in Rondel $v$ Worsley explained the consequence of extending liability in negligence to barristers. According to the House of Lords, it might 'undermine the willingness of barristers to carry out their duties to the court. ${ }^{53}$ The House of Lords in the above case unanimously agree that the true basis of the immunity accorded to Legal Practitioners in respect of court proceedings lie in public policy. Secondly, the basis for this immunity is tied to the principle that once a trial has been concluded, it cannot be re-opened again. If clients were given the opportunity to sue their lawyers for cases conducted by them, it will mean a re-trial of the original action. This would lead to lengthy litigations which is contrary to public interests. Thirdly, a lawyer has a duty to accept any client who requests for his service. However the majority of the House of Lords unanimously agreed that a lawyer should not be immune from negligence for work that is unrelated with the cases in court, in such instances he would be liable for any careless or reckless act. In Saif Ali v Sydney Mitchell and $\mathrm{Co}^{54}$ the court held that the immunity extended to pre-trial work related to the case. According to the court, the status of the barrister is special and as such some immunity is needed even if the client suffers loss.

\footnotetext{
${ }^{50} 157$ Eng. Rep 964, 968 (Ex. Ch. 1859) (Crompton, J., concurring).

51 (1969) 1 AC 191, 227

${ }^{52}$ Ibid

${ }^{53}$ Ibid HL 1967 by Lord Morris of Borth-Y-Gest

${ }^{54}$ Supra note 14
} 


\subsubsection{Advocate for the removal of Lawyers immunity clause}

In Nigeria, the rule of law exempting lawyers from negligence suits in the conduct of proceedings in court has been adopted in Section 9(3) of the LPA. The current law in Nigeria is that lawyers cannot be sued for professional negligence in the conduct of proceedings in a court, tribunal or other body. ${ }^{55}$ There have been several advocates for the removal of the legal practitioner's immunity in Nigeria. In England, America and Canada the absolute immunity has been abolished, there has however been a clamour that such immunity should also be abolished in Nigeria. England where we inherited the rule of law itself no longer practices such immunity. The House of Lords had ruled in England that Barristers and Solicitors are no longer immune from being sued in negligence in the conduct of proceedings. ${ }^{56}$ Reversing the decision in Rondel $v$ Worsley ${ }^{57}$ the House of Lord declared that the immunity in England no longer exists. According to the Judges maintaining the immunity especially in criminal proceedings will create 'anomalies. ${ }^{58}$ The house of lord further stated that removing the immunity should not affect the duty of the lawyer to the court. ${ }^{59}$ The judges felt that the removal was necessary to preserve the confidence in the legal system. One cannot but wonder whether its removal in Nigeria will be sufficient to restore back the confidence in the legal system. The challenges in the legal systems and the professional misconduct of lawyers are too numerous to count. A reformation of the legal practice and systems entails not just concentration on one aspect alone but on every aspect of the legal system. Some of the arguments for the removal of the lawyer immunity in Nigeria bother on the fact that it contravenes one of the major foundations of the Nigerian constitution which is equality before the law. ${ }^{60}$ Some writers have argued that the removal of the lawyer's immunity cannot hold ground in the light of the Nigerian Situation" 61 However it is not clear what constitutes the peculiarity of the Nigerian situation to justify the removal by the writers. Arguments based on the Nigerian situations are merely excuses for the failure of a system that refuses to work. It is however reasonable to follow the decision of the House of Lords which has made it clear that the abolition of the immunity may help to strengthen the legal system.

Although lawyers in Nigeria are exempted from negligence in the conduct of proceedings, the legal profession has provided in-house machinery for dealing with cases of professional misconduct by lawyers. The major avenue, in which the bar ensures that the highest standards of code of conduct are maintained in the legal profession is through the Legal Disciplinary Committee. ${ }^{62}$ The committee was established under section 10 of the LPA whose duty is to determine cases of any complaint against any practitioners for misbehaviours. Where a practitioner is found guilty of infamous conduct, his name may be stroke off the roll of legal practitioners. ${ }^{63}$ In this regard, a lot of lawyers have been suspended or disbarred for infamous

\footnotetext{
${ }^{55} \mathrm{~S} 9(3)$ LPA

${ }^{56}$ Arthur J.S Hall v Simons(2002) 1 AC 615

57 Supra note 51

58 Terence Shaw 'Barristers and Solicitors Loose Key Immunity'

<https://www.telegraph.co.uk/news/uknews/1349627/Barristers-and-solicitors-lose-keyimmunity.html>accessed 7 December 2020

${ }^{59}$ Supra note 51,191

${ }^{60}$ E.S Nwauche 'The Need to Review the Immunity of Legal Practitioners For Negligence in Nigeria' (2002)44(4)Journal of the Indian Law institute, 574

${ }^{61}$ Ibid

${ }^{62}$ Okike v Legal Practitioners Disciplinary Committee (2005) 15 NWLR (Pt. 949) 471

${ }^{63}$ Supra note 35; L.P.D.C. v. Gani Fawehinmi (1985) NWLR (Pt.7) 300
} 
conduct. Suffice it to say that this has still not helped to reduce the number of misconduct by lawyers in Nigeria.

With the numerous cases of negligent misconduct by lawyers in Nigeria, it is safe to agree with other writers that the immunity should be removed as it adds no value whatsoever to the profession. In order to ensure dedication and commitment of lawyers to the integrity of the advocacy profession it is necessary that the immunity be removed. Removal of the immunity may reduce the laxity and unseriousness in which some lawyers handle cases in Nigeria. In order to bring sanity to the legal profession lawyers may have to be held responsible for how they handle cases during court proceedings.

\subsection{CONCLUSION}

The findings presented in this paper have proven that the tort of negligence is an important aspect of law in the legal profession, particularly the law of professional negligence. On the whole, the standard of care required of legal practitioners is an elevated one. Thus the exemption of lawyers from liability for negligence is inconsistent with the principle of professional negligence. The fact portrayed in this study points out to some of the instances of professional misconduct by lawyers in Nigeria which shows that the standard in the legal profession has fallen. An immunity of such a nature may further weaken the quality of the profession. This study explored some of the arguments put forth for the removal of lawyer's immunity, however maintaining the overall cleansing of the profession.

A study on professional negligence is of great significance especially in the area of legal practice. If the average man will have confidence in the legal system, there is a need to take the issues discussed in this paper seriously. These are recurrent issues which bother on professional misconducts by legal practitioners in Nigeria. When lawyers are known to exhibit carelessness and recklessness in the conduct of their case it weakens the fabric for which the legal profession stands on. Accordingly, a lawyer ought to preserve the tenents of the profession at all times. If the standard of the profession is to be sustained, such issues as professional negligence must be dealt with. Furthermore, the topic of professional negligence is important in order to address the numerous cases of negligent misconduct by lawyers. Ensuring liability for Professional negligence or misconduct will make legal practitioners more cautious in handling their client's case, thus ensuring that the standards of the profession are upheld.

The law on professional negligence in Nigeria is not entirely settled as it relates to the issue of the lawyer's immunity. Therefore, it is proposed that continuous arguments for the removal of the lawyer's immunity be re-considered for its possible removal. The Bar requires continuous high standards in the practice of law in Nigeria so that clients and the general public can repose their confidence in the legal profession. For this reason, lawyers should work towards personal development and training to maintain their legal knowledge and skills. In order to help lawyers maintain competence in their profession, regular conferences and workshops that address competency areas should be held regularly. No man can know it all, even the most successful lawyer is still constantly learning. Therefore the senior lawyers have a duty to help train young lawyers who are struggling in the practice of law. It is often the case that senior lawyers do not pay attention to the needs of the younger lawyers, they leave them to fend for themselves. This shouldn't be the case. Thus to develop competence in the 
Scholarly Journal of Advanced Legal Research | ISSN: 2782-8220

Vol. 1, Issue 5 (May, 2021) |www.ijaar.org

Journal DOI: www.doi.org/10.46654/SJALR

Article DOI: www.doi.org/10.46654/SJALR.1541

legal profession the joint efforts of the senior lawyers who have developed competence is needed to help raise more competent lawyers. 